\title{
Effects of nitrogen rates on yield, yield components, and other related attributes of different rapeseed (Brassica napus L.) varieties
}

\author{
Mohammed Yahbi ${ }^{1,2}$ (D) Abdelghani Nabloussi $^{3}$ (D) Abdelwahed Maataoui $^{4}$, Nabila El Alami ${ }^{2}$ (D), \\ Abdellatif Boutagayout ${ }^{5}$ (D) and Khalid Daoui ${ }^{1, *}$ (D) \\ ${ }^{1}$ Research Unit of Agronomy and Plant Physiology, National Institute of Agricultural Research, Regional Agricultural Research Center \\ of Meknes, Meknes, Morocco \\ ${ }^{2}$ Laboratory of Biotechnologies and Valorization of Bio-Resources (BioVaR), Department of Biology, Faculty of Science, Moulay Ismail \\ University, Meknes, Morocco \\ ${ }^{3}$ Research Unit of Plant Breeding and Plant Genetic Resources Conservation, National Institute of Agricultural Research, Regional \\ Agricultural Research Center of Meknes, Meknes, Morocco \\ 4 Department of Plant Agronomy and Plant Breeding, National School of Agriculture, Meknes, Morocco \\ 5 The Environment and Soil Microbiology Unit, Faculty of Sciences, Moulay Ismail University, Meknes, Morocco
}

Received 21 September 2021 - Accepted 10 January 2022

\begin{abstract}
Rapeseed is one of the most important oilseed crops in the world and, in Morocco, it may contribute to the improvement of food security in edible oils through developing performant cultivars and optimizing the crops management including nitrogen fertilization. The objective of this study was to evaluate the response of different Moroccan varieties to nitrogen application. Field trials were carried out at the experimental station of National School of Agriculture in Meknes, during two cropping seasons (2017-2018 and 2018-2019). Five varieties ("Narjisse", "Moufida", "Alia", "Adila", and "Lila") were combined to different nitrogen rates $(0,30$, 60 , and $\left.90 \mathrm{~kg} \mathrm{Nha}^{-1}\right)$. The experimental design adopted is a split split-plot with three replications, where nitrogen treatment was affected to main plot, variety to subplot, and year to sub-subplot. Results showed that dry matter, harvest index, oil content, seed yield per plant and yield components were significantly affected by nitrogen rates, with an upward trend in seed yield as the nitrogen rates increased. On average, seed yield increased by $50.33 \%$ for application of $90 \mathrm{~kg} \mathrm{Nha}^{-1}$ compared to the control (without $\mathrm{N}$ fertilization). However, oil content declined from $41.08 \%$ to $37.81 \%$ with the increase of nitrogen level from 0 to $90 \mathrm{~kg} \mathrm{~N} \mathrm{ha}^{-1}$. Additionally, for the other traits studied, the highest mean values were observed for $90 \mathrm{~kg} \mathrm{~N} \mathrm{ha}^{-1}$, except harvest index which exhibited the greatest value for $60 \mathrm{~kg} \mathrm{Nha}^{-1}$. Variation among the varieties was significantly large for all traits studied with a superiority of the variety "Alia" for seed yield per plant (9.82 $\left.\mathrm{g} \mathrm{plant}^{-1}\right)$, number of pods per plant (151), and number of seeds per pod (24.05).
\end{abstract}

Keywords: rapeseed / nitrogen fertilization / seed yield components / dry matter / oil content

\begin{abstract}
Résumé - Effet de la dose d'azote sur le rendement, ses composantes et d'autres caractères associés de différentes variétés de colza. Le colza est l'une des cultures oléagineuses les plus importantes dans le monde. À travers le développement de cultivars performants et une bonne gestion de la culture, y compris la fertilisation azotée, le colza pourrait contribuer à l'amélioration de la sécurité alimentaire en matière d'huile végétale au Maroc. Pour l'évaluation de la réponse de cinq variétés marocaines de colza («Narjisse», «Moufida», «Alia», «Adila» et «Lila») à la dose d'azote appliquée $(0,30,60$ et $90 \mathrm{~kg} \mathrm{Nha}^{-1}$ ), deux essais au champ ont été installés sur la parcelle d'expérimentation de l'École nationale d'agriculture de Meknès, durant les campagnes agricoles (2017-2018 et 2018-2019). Le dispositif expérimental utilisé est un split split-plot, avec trois répétitions, où le traitement azoté est affecté à la grande parcelle et la variété est assignée à la petite parcelle. Les résultats ont montré que l'effet du traitement azoté a été hautement significatif sur tous les paramètres étudiés. Le rendement en graines a augmenté avec
\end{abstract}

*Correspondence: khalid. daoui@inra.ma 
l'augmentation de la dose d'azote appliquée, avec une augmentation de $50,33 \%$ de 0 à $90 \mathrm{~kg} \mathrm{Nha}^{-1}$. Également, pour les autres paramètres étudiés, les valeurs les plus élevées ont été observées avec $90 \mathrm{~kg} \mathrm{Nha}^{-1}$, à l'exception de l'indice de récolte qui a donné la valeur la plus élevée avec $60 \mathrm{~kg} \mathrm{Nha}^{-1}$. Également, l'effet de la variété a été significatif sur tous les paramètres étudiés, avec une supériorité de la variété «Alia» pour le rendement en graines par plante $\left(6,82 \mathrm{~g}_{\text {plante }}^{-1}\right)$, le nombre de siliques par plante (151) et le nombre de graines par silique $(24,05)$.

Mots clés : colza / fertilisation azotée / rendement en graines / matière sèche / teneur en huile

\section{Highlights}

- Response of five rapeseed varieties (V) to different nitrogen $(\mathrm{N})$ rates was investigated under field conditions in Morocco. $\mathrm{N}$ and $\mathrm{V}$ induce a significative effects with no interaction $\mathrm{V} \times \mathrm{N}$.

- $\mathrm{N}$ rate of $90 \mathrm{~kg} \mathrm{Nha}^{-1}$ was the best regardless of $\mathrm{V}$ studied. For all $\mathrm{N}$ rates combined, the varieties "Alia" and "Moufida" give the best seed and oil yield.

\section{Introduction}

Rapeseed (Brassica napus L.) is one of the most important oilseed crops in the world. It is mainly cultivated for its seeds, which are rich in oil (on average $43 \%$ of the total composition) but also in protein, which achieve an average of $19 \%$ of the total composition (Poisson et al., 2019). Rapeseed oil is the third vegetable oil consumed in the world after soybean and palm oil, and contribute with approximately $13 \%$ of the global oil supply (Raman et al., 2019). This crop covers more than 34.03 Mha all around the world, ensuring a production of about 70.51 Mt (FAOSTAT, 2021).

In Morocco, oilseed crops (sunflower and rapeseed) are cultivated on an area of 35,511 ha, with a total production of 38,549 tons (Anonymous, 2021). Rapeseed crop occupies more than 13,000 ha. The national production is thus too low showing a remarkable deficit in edible oils in Morocco, which remains heavily dependent on imports to supply the national market (Nabloussi, 2015). However, oilseed crops, including rapeseed, have high yield potential allowing it to contribute to increase the level of edible oil food security.

Nitrogen is one of the most important growth factors improving biomass, and seed yield of rapeseed (Brennan and Bolland, 2007). In fact, this crop requires high nitrogen (Ahmadi and Bahrani, 2009; Holmes, 1980; Riar et al., 2020). About 25\% more than wheat (Hocking et al., 1997). Although rapeseed has good nitrogen uptake efficiency, only $50 \%$ of the absorbed nitrogen originating from fertilizers is mobilized to the harvested seeds (Schjoerring et al., 1995). Unabsorbed nitrogen is not only a considerable economic loss, but also a serious damage to the surrounding ecosystems (Galloway et al., 2013). Competitive production depends primarily on adequate nitrogen application. Choosing the correct doses, source, and timing of nitrogen fertilizer application is therefore an important aspect of successful rapeseed production.
This choice depends on several factors such as climatic conditions, availability of nitrogen in the soil profile, and especially the genetic characteristics of the varieties (Zhang et al., 2010).

Several studies have shown the effect of nitrogen supply on yield and yield components of rapeseed (Ahmad et al., 2011; Al-Solaimani et al., 2015; Hocking et al., 1997; Naderifar and Daneshian, 2012; Öztürk, 2010; Zuo et al., 2019). In general, appropriate application of nitrogen can increase rapeseed yield by improving vegetative growth and reproductive development, as well as increasing seed yield (Ma and Herath, 2016; Lin et al., 2020). However, increasing nitrogen fertilization rates leads to a decrease in seed oil content (Jackson et al., 1993; Jackson, 2000; Hocking and Stapper, 2001).

Genotype variation in rapeseed for dry matter, yield components, seed yield and oil content in response to nitrogen application has been reported by many authors (Asare and Scarisbrick, 1995; Özer, 2003; Balint and Rengel, 2008; Stahl et al., 2019). Seed yield differed significantly among rapeseed genotypes especially under limiting nitrogen supply, with marked interaction with nitrogen (Schulte auf'm Erley et al., 2011). In this sense, Rathke et al. (2006) reported that the response of rapeseed cultivars to increasing nitrogen application varied significantly and was also affected by many environmental factors such as weather, soil type, soil moisture, and residual fertilization, especially nitrogen (Fig. 1).

Between 2008 and 2017, five Moroccan rapeseed varieties were released and registered by the National Institute of Agricultural Research (INRA). They are all productive and adapted to local environmental conditions, with high seed yield and oil content. However, no information is available about their efficiency and response to nitrogen application. Therefore, the present study aims to assess and characterize these varieties' response to different nitrogen rates and to identify the most efficient ones.

\section{Materials and methods}

\subsection{Plant material, nitrogen treatments and field experiment}

Five rapeseed varieties developed by INRA, namely "Narjisse", "Moufida", "Alia", "Adila", and "Lila" (the first three varieties are lines, while the other two are synthetic varieties), were tested under four nitrogen treatments: $\mathrm{N}_{0}$ (without nitrogen application), $\mathrm{N}_{30}\left(30 \mathrm{~kg} \mathrm{Nha}^{-1}\right.$ applied at sowing), $\mathrm{N}_{60}$ (split as $30 \mathrm{~kg} \mathrm{~N} \mathrm{ha}^{-1}$ at sowing and $30 \mathrm{~kg} \mathrm{~N} \mathrm{ha}^{-1}$ at rosette stage), and $\mathrm{N}_{90}$ (split as $30 \mathrm{~kg} \mathrm{Nha}^{-1}$ at sowing, $30 \mathrm{~kg} \mathrm{Nha}^{-1}$ at rosette stage and $30 \mathrm{~kg} \mathrm{Nha}^{-1}$ at flowering). Treatments were applied manually by the same person. 


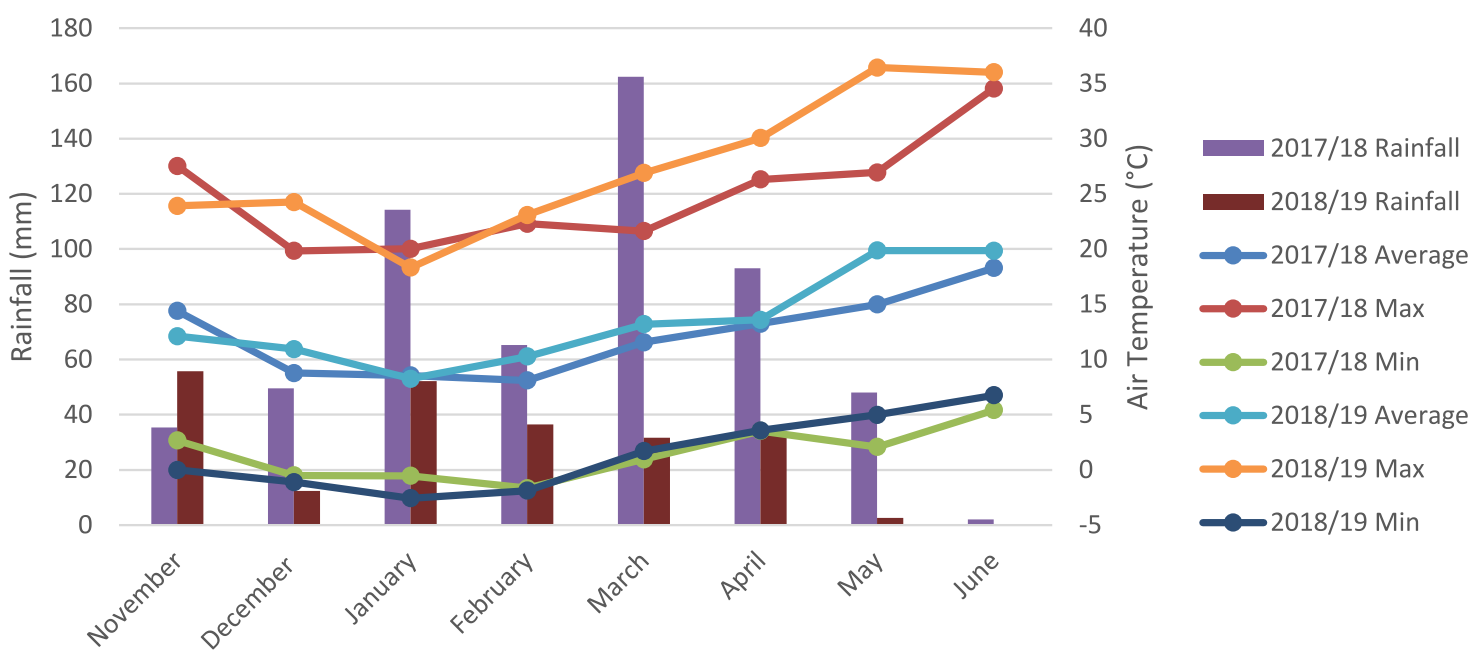

Fig. 1. Total monthly precipitation (bars) and air temperatures (lines) recorded in the experimental station during two cropping seasons (2017/ 2018 and 2018/2019).

The nitrogen fertilizer used was ammonium nitrate with $33.5 \%$ nitrogen.

The field experiment was conducted during two consecutive cropping seasons, 2017/2018 and 2018/2019, at the Research Farm of National School of Agriculture (ENA) in Meknes, Morocco (33 $\left.84^{\prime} \mathrm{N}, 5^{\circ} 47^{\prime} \mathrm{W}\right)$. The soil is a clay loam soil, belonging to the class of calcimagnesic soils, the subclass of carbonate, and the group of brown limestone. Before sowing, soil samples were taken from research field at a depth of 0-30 cm for analysis in both years and the results are shown in Table 1. The five rapeseed varieties were combined with the four nitrogen levels, according to a split split-plot experimental design with three replications. Nitrogen treatment was affected to main plots, variety treatment to subplot, and year to subsubplot. At each replication, there were four plots having a size of $9 \mathrm{~m} \times 5 \mathrm{~m}$, each with five subplots (varieties). Each variety is represented by three rows of $5 \mathrm{~m}$ long and $0.60 \mathrm{~m}$ apart. Sowing depth was $2-3 \mathrm{~cm}$ and planting density was 30 plants per meter square.

\subsection{Plant samples and measurements}

At maturity, five individual plants per variety and per nitrogen treatment, from the central row in each subplot, were randomly taken for measurements and data collection. The height of the plant was the length of the main stem. Number of seeds per pod was estimated by counting the seeds of a sample of five pods per plant. Number of primary branches per plant was numbered as the branches of the main stem, while number of secondary branches was calculated as the sum of the branches developed from the primary branches. Number of pods per plant was determined for each sampled plant and 1000 -seeds weight was determined using a precision balance. Regarding dry matter and seed yield per plant, the five sampled plants were sun-dried and weighted to determine the dry matter per plant. After that, each plant were threshed separately, the yield of clean seed for each plant was weighed to estimate the seed yield per plant. Harvest index was calculated as the ratio of seed yield per plant to biomass per plant. Finally, seed oil content was rapidly determined in $9 \%$ moisture seeds by Near
Table 1. Soil characteristics before sowing for 2017/2018 and 2018/2019 cropping seasons.

\begin{tabular}{lcc}
\hline Characteristic & \multicolumn{2}{c}{ Cropping season } \\
\cline { 2 - 3 } & $2017-2018$ & $2018-2019$ \\
\hline Organic matter (\%) & 1.5 & 1.63 \\
$\mathrm{P}_{2} \mathrm{O}_{5}$ (Olsen) (ppm) & 13.9 & 19.2 \\
$\mathrm{~K}_{2} \mathrm{O}(\mathrm{ppm})$ & 26.8 & 35.3 \\
Total nitrogen (\%) & 2.79 & 3.22 \\
pH & 8.78 & 8.65 \\
Electric conductivity in Ms & 0.29 & 0.3 \\
\hline
\end{tabular}

Infra-Red Spectroscopy (NIRS) technique, using MINIFRA Smart.

\subsection{Data analysis}

Data collected from both years were subjected to analysis of variance and analysis of correlation, using the general linear model (GLM) and correlation procedures of the software package SAS for Windows (version 9.1.3). In this study, all the factors investigated were considered as fixed factor. In case of significant differences among varieties and nitrogen treatments, Duncan's new multiple range test was applied to compare the means ( $5 \%$ probability threshold).

\section{Results}

\subsection{Weather conditions}

The weather conditions of both cropping seasons are shown in Figure 2. There was considerable variation in rainfall distribution and amounts between the two seasons. During $2017 / 2018$ cropping season, rainfall was relatively high $(569.8 \mathrm{~mm})$ and well distributed throughout the crop cycle from sowing to harvest. Whereas, during 2018/2019 cropping season, rainfall was low $(224.2 \mathrm{~mm})$ and poorly distributed. 


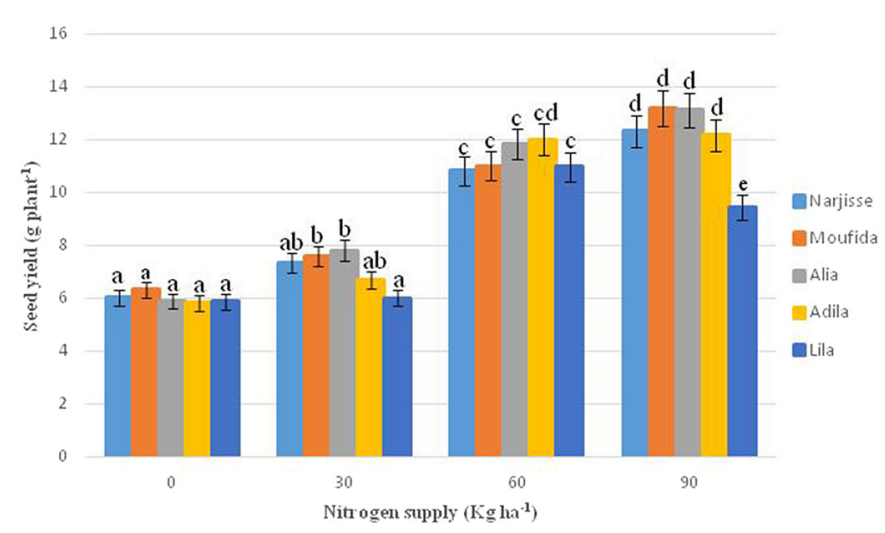

Fig. 2. Seed yield of five rapeseed varieties conducted under different nitrogen rate applied.

Precipitations of the first season were, particularly, low at the beginning of the crop cycle, which caused water stress during the early stages of rapeseed growth and development. To overcome this water deficit at those critical phases (seedling), a supplemental irrigation of $50 \mathrm{~mm}$ was applied at the end of December 2018. The air temperature had almost the same trend in both seasons with slightly higher temperatures in $2018 / 2019$ than in $2017 / 2018$. Monthly temperature averages ranged from 8.09 and $8.25^{\circ} \mathrm{C}$, recorded in February and January for the $2017 / 2018$ and $2018 / 2019$ seasons respectively, to 18.28 and $19.85^{\circ} \mathrm{C}$, registered in June for the $2017 / 2018$ and 2018/2019 seasons respectively. In both seasons, December, January and February were the coldest months, while May and June were the warmest.

\subsection{Seed yield}

Statistical analysis revealed highly significant effect of year and nitrogen rate on seed yield per plant, also the differences among varieties were statistically significant for this trait (Tab. 2). No significant effect of the interaction between nitrogen and genotype and between genotype and year on seed yield was noticed. Seed yield of all the five varieties was improved considerably by increasing nitrogen application from 0 to $90 \mathrm{~kg} \mathrm{Nha}^{-1}$. Indeed, regardless of the studied varieties, the highest yields were obtained for treatments 60 and $90 \mathrm{~kg} \mathrm{~N} \mathrm{ha}^{-1}$, with 11.33 and 12.04 g plant $^{-1}$, respectively, compared to 5.98 and 7.08 g plant $^{-1}$, respectively, registered for 0 and $30 \mathrm{~kg} \mathrm{~N} \mathrm{ha}^{-1}$ treatments. However, nitrogen application of 60 and $90 \mathrm{~kg} \mathrm{~N} \mathrm{ha}^{-1}$ gave seed yields statistically comparable (Tab. 2). Figure 2 illustrates the responses of cultivars to different $\mathrm{N}$ rates for seed yield. Regarding the variety effect, and for all $\mathrm{N}$ rates combined, seed yield varied from $8.20 \mathrm{~g}^{\text {plant }}{ }^{-1}$ for "Lila" which was significantly smallest than the others varieties. To $9.82 \mathrm{~g} \mathrm{plant}^{-1}$ for "Alia" which was not significantly different from the remaining others varieties "Narjisse", "Moufida", and "Adila" which having yielded 9.29, 9.70, and 9.31 g plant $^{-1}$, respectively.

\subsection{Dry matter}

Dry matter (DM) biomass of the five varieties rose with the increase of nitrogen dose from $\mathrm{N}_{0}$ to $\mathrm{N}_{3}$ except for "Lila" which showed a slight decrease in dry matter from $\mathrm{N}_{2}$ to $\mathrm{N}_{3}$
(Fig. 2). Dry matter was significantly influenced by the main effects of the variety, year, $\mathrm{N}$ rate, the interaction of these two latter, and the interaction of year and $\mathrm{N}$ rates (Tab. 2). The increase in $\mathrm{DM}$ from $\mathrm{N}_{0}$ to $\mathrm{N}_{3}$, for all varieties combined, was $63.4 \%$. The highest DM was $41.56 \mathrm{~g}$ plant $^{-1}$ obtained by applying $90 \mathrm{~kg} \mathrm{Nha}^{-1}$ (the $\mathrm{N}_{30}$ treatment), while the lowest DM was $25.43 \mathrm{~g} \mathrm{plant}^{-1}$ produced in control treatment (absence of any $\mathrm{N}$ fertilization). Also, DM production varied among varieties tested; the highest DM were 34.78, 34.12, and 34.03 g plant $^{-1}$ accumulated by "Alia", "Adila", and "Narjisse", respectively, while "Lila" showed the lowest DM of $31.47 \mathrm{~g} \mathrm{plant}^{-1}$. The significant effect of variety $\times$ nitrogen interaction revealed that the different varieties arranged and reacted differently to the different nitrogen levels. Also the interaction year $\times$ nitrogen was highly significant which mean that weather conditions were an important factor that affected the nitrogen effect.

\subsection{Harvest index}

The year, variety, nitrogen rate, and the interaction of these two latters had a significant effect on harvest index (HI) (Tab. 2). The treatments 60 and $90 \mathrm{~kg} \mathrm{~N} \mathrm{ha}^{-1}$ gave the highest HI, with an average value of $28.95 \%$ and $28.43 \%$ respectively, whereas the lowest HI, 22.95\%, was observed under $\mathrm{N}_{0}$ treatment with no nitrogen fertilization. Regardless of nitrogen rates, HI ranged from $27.42 \%$, observed in "Alia", to $24.90 \%$, recorded in "Lila" (Fig. 3).

\subsection{Oil content}

Results of analysis of variance indicated a highly significant effect of year, variety and nitrogen rate on oil content (Tab. 2). However, no significant effect of the interaction genotype $\times$ nitrogen was observed. Indeed, oil content decreased with the increase of nitrogen supply, which submits a negative relationship between oil content and nitrogen rate (Fig. 4). It decreased significantly from $41.08 \%$ for $\mathrm{N}_{0}$ treatment to an average of 37.99 and $37.81 \%$ for 60 and $90 \mathrm{~kg} \mathrm{~N} \mathrm{ha}^{-1}$ treatments respectively (Tab. 2). Also, seed oil content varied significantly among the varieties studied. In fact, this parameter ranged from 40.11 to $37.69 \%$ in "Lila" and "Narjisse", respectively.

\subsection{Plant height}

Results of analysis of variance indicated that year, nitrogen application rate, variety, and the interaction of nitrogen by variety had a significant effect on plant height (Tab. 3). The highest plant height $(125 \mathrm{~cm})$ was recorded with the $90 \mathrm{~kg} \mathrm{~N} \mathrm{ha}^{-1}$ treatment and was statistically equal to that recorded by the $60 \mathrm{~kg} \mathrm{~N} \mathrm{ha}^{-1}$ treatment $(123 \mathrm{~cm})$. On the other hand, the lowest plant height $(105 \mathrm{~cm})$ was recorded in $\mathrm{N}_{0}$ (without $\mathrm{N}$ application). The five varieties studied exhibited a distinct response to $\mathrm{N}$ rate for plant height, with "Lila" and "Adila" being the tallest, having an average height of about $121 \mathrm{~cm}$ and "Moufida" the shortest with a height of $112 \mathrm{~cm}$ (Tab. 3). 
Table 2. Mean effect of year, variety, and nitrogen rate on dry matter, harvest index, oil content, and oil yield in rapeseed (averaged data over two years).

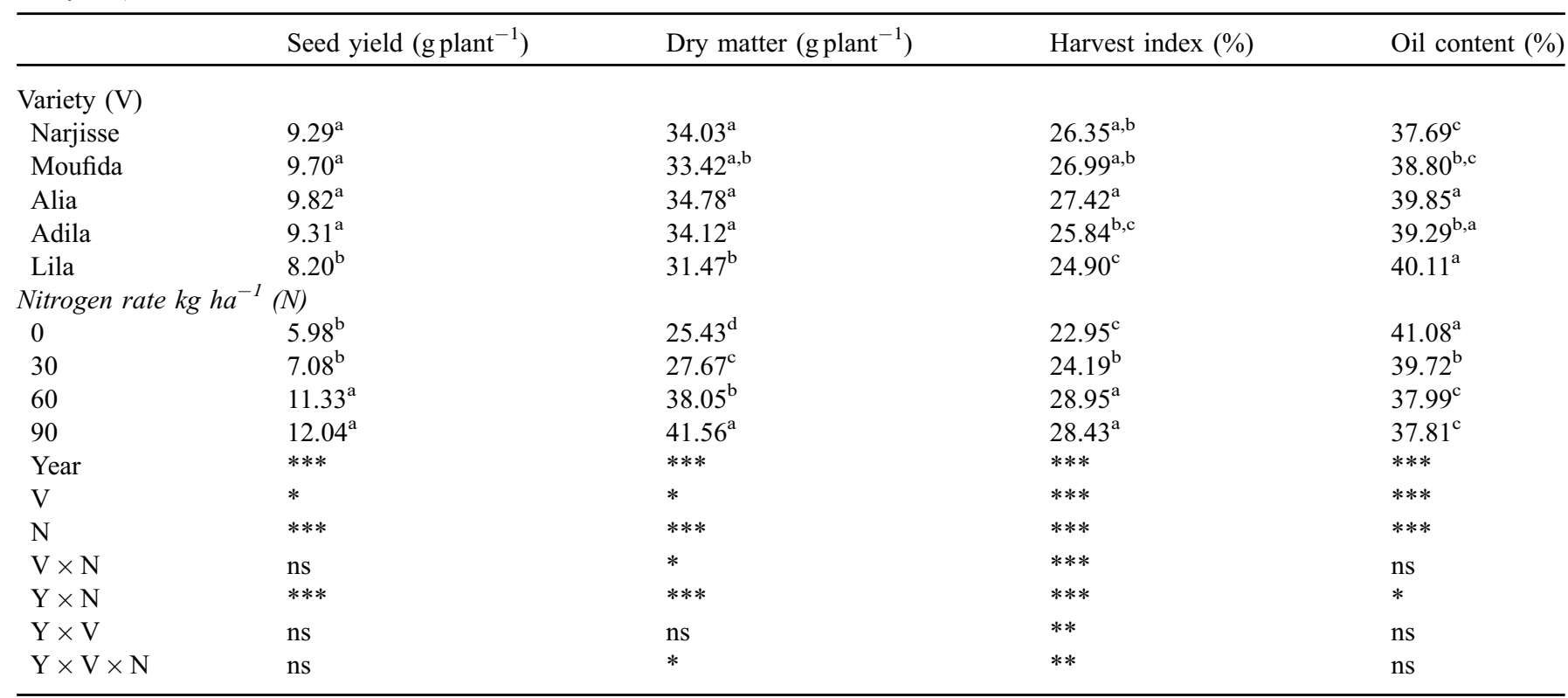

ns: not significant; $*{ }^{* *}$, and ${ }^{* * *}$ : significant at $0.05,0.01$, and 0.001 probability level, respectively. For each main effect, values within columns followed by the same letters are not significantly different according to Duncan's test

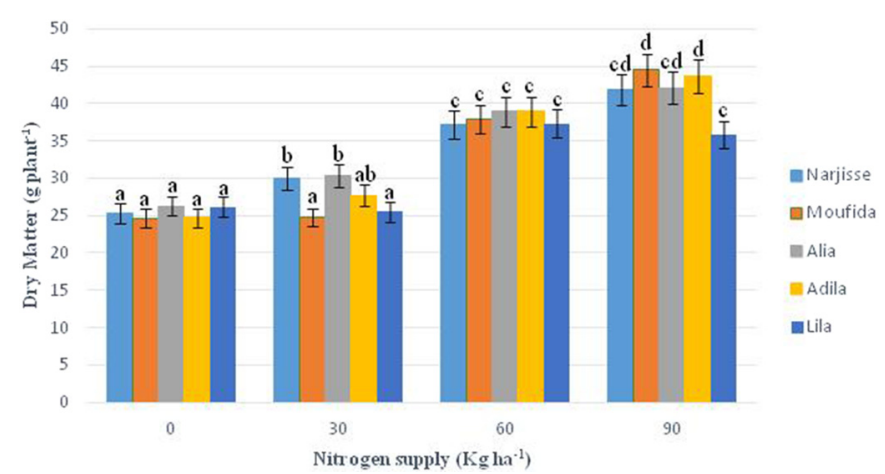

Fig. 3. Dry matter of five rapeseed varieties under different nitrogen rate applied.

\subsection{Yield components}

The number of primary branches (NPB) was highly and significantly influenced by variety and nitrogen rate. However, their interaction had no significant effect on it (Tab. 3). This parameter varied from 4.27 in the variety "Alia" to 4.86 in the variety "Adila". Regarding N fertilization, the highest NBP (5.12) was obtained for the highest $\mathrm{N}$ rate $\left(90 \mathrm{~kg} \mathrm{Nha}^{-1}\right)$ and the lowest NBP (4.03) for the lowest $\mathrm{N}$ rate $\left(0 \mathrm{~kg} \mathrm{Nha}^{-1}\right)$. Similarly, the number of secondary branches (NSB) was significantly affected by the year, nitrogen rate and the variety. The highest mean value (6.39), was observed with the $90 \mathrm{~kg} \mathrm{Nha}^{-1}$, while the lowest, 4.43 , was recorded with the $30 \mathrm{~kg} \mathrm{Nha}^{-1}$. With regard to the investigated varieties, "Alia" exhibited the lowest branching, with an average NSB of 4.4, whereas "Narjisse" showed the highest branching, with an

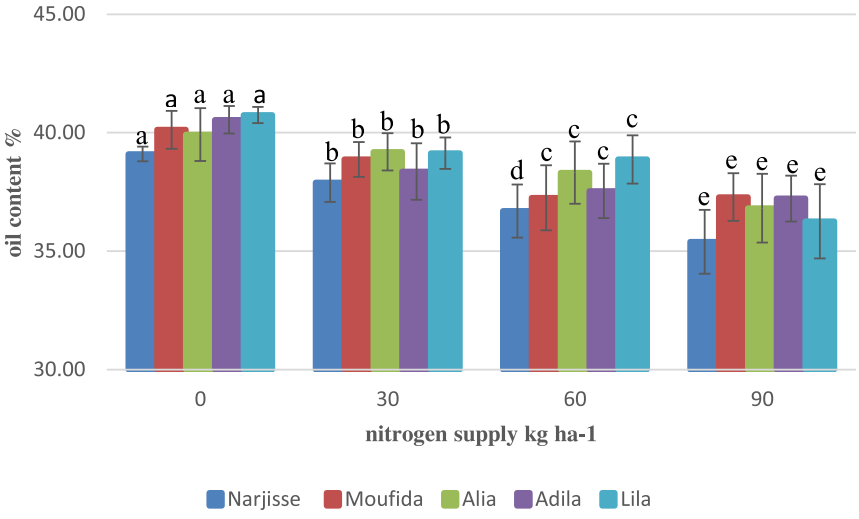

Fig. 4. Oil content of five rapeseed varieties according to nitrogen rate application (two-year average data).

average NPB of 6.02. A significant effect of nitrogen rate and year on the number of pods per plant was revealed. Regardless of the varieties, this trait ranged from 112 pods, for $\mathrm{N}_{0}$ treatment, to 180 pods, for $90 \mathrm{~kg} \mathrm{~N} \mathrm{ha}^{-1}$ (Tab. 3). For all N treatments combined, number of pods per plant was varied from 139 , in the variety "Lila", to 151 , in the variety "Alia". For all $\mathrm{N}$ treatments combined, the number of pods per plant varied from 139 for the variety "Lila" to 151 for the variety "Alia". Results of analysis of variance showed no significant effect of nitrogen $\times$ variety interaction for seeds per pod. Varieties differed significantly in seeds per pod (Tab. 3). "Narjisse" and "Moufida" have similar seeds per pods with an average of 22.48 and 23.26 seeds pod $^{-1}$, which were the lowest, followed by "Lila" with 23.71 seeds $\operatorname{pod}^{-1}$. The highest seeds pod $^{-1} 23.78$ and 24.05 were recorded by 
Table 3. Mean effect of year, variety, and nitrogen rate on yield and yield components in rapeseed (averaged data over two years).

\begin{tabular}{|c|c|c|c|c|c|c|}
\hline Source of variation & $\begin{array}{l}\text { Plant } \\
\text { height }(\mathrm{cm})\end{array}$ & $\begin{array}{l}\text { Number of primary } \\
\text { branches }\end{array}$ & $\begin{array}{l}\text { Number of secondary } \\
\text { branches }\end{array}$ & Pods plant ${ }^{-1}$ & Seeds pod ${ }^{-1}$ & $\begin{array}{l}1000 \text {-seed } \\
\text { weight }(\mathrm{g})\end{array}$ \\
\hline \multicolumn{7}{|l|}{$\operatorname{Variety}(V)$} \\
\hline Moufida & $112^{\mathrm{c}}$ & $4.4^{\mathrm{b}}$ & $5.23^{\mathrm{b}}$ & $149^{\mathrm{a}}$ & $23.26^{\mathrm{b}}$ & $3.54^{\mathrm{b}}$ \\
\hline Alia & $116^{\mathrm{b}}$ & $4.27^{\mathrm{b}}$ & $4.4^{\mathrm{c}}$ & $151^{\mathrm{a}}$ & $24.05^{\mathrm{a}}$ & $3.42 \mathrm{c}$ \\
\hline Adila & $119^{\mathrm{a}}$ & $4.84^{\mathrm{a}}$ & $5.73^{\mathrm{a}, \mathrm{b}}$ & $142^{\mathrm{a}}$ & $23.78^{\mathrm{a}}$ & $3.52^{\mathrm{b}, \mathrm{c}}$ \\
\hline \multicolumn{7}{|c|}{$N$ treatment $\mathrm{kg} \mathrm{ha}^{-1}(N)$} \\
\hline 0 & $105^{\mathrm{b}}$ & $4.3^{\mathrm{b}}$ & $4.53^{\mathrm{b}}$ & $112^{\mathrm{b}}$ & $21.78^{\mathrm{b}}$ & $3.21^{\mathrm{d}}$ \\
\hline 30 & $111^{\mathrm{b}}$ & $4.05^{\mathrm{b}}$ & $4.43^{\mathrm{b}}$ & $117^{\mathrm{b}}$ & $22.24^{\mathrm{b}}$ & $3.46^{\mathrm{c}, \mathrm{d}}$ \\
\hline 60 & $123^{\mathrm{a}}$ & $4.87^{\mathrm{a}}$ & $5.74^{\mathrm{a}, \mathrm{b}}$ & $167^{\mathrm{a}}$ & $24.23^{\mathrm{a}}$ & $3.67^{\mathrm{b}}$ \\
\hline 90 & $125^{\mathrm{a}}$ & $5.15^{\mathrm{a}}$ & $6.39^{\mathrm{a}}$ & $180^{\mathrm{a}}$ & $25.19^{\mathrm{a}}$ & $3.81^{\mathrm{a}}$ \\
\hline Year (Y) & $* * *$ & $* * *$ & $* * *$ & $* * *$ & $* * *$ & $* * *$ \\
\hline $\mathrm{Y} \times \mathrm{V}$ & ns & $* * *$ & $* * *$ & $*$ & $* *$ & ns \\
\hline $\mathrm{Y} \times \mathrm{V} \times \mathrm{N}$ & ns & $*$ & $*$ & $* *$ & $\mathrm{~ns}$ & $\mathrm{~ns}$ \\
\hline
\end{tabular}

ns: not significant; ${ }^{*}, *$, and $* * *$ : significant at $0.05,0.01$, and 0.001 probability level, respectively. For each main effect, values within columns followed by the same letters are not significantly different.

"Adila" and "Alia" respectively. The nitrogen rate had a significant effect on the number of seeds per pod. Seeds pod ${ }^{-1}$ increase with increasing of nitrogen application rate. The highest seeds pod ${ }^{-1}$ were obtained for 60 and $90 \mathrm{~kg} \mathrm{Nha}^{-1}$ with an average of 24.23 and 25.19 seeds pod $^{-1}$ respectively, which were significantly greater than those obtained for $\mathrm{N}_{0}$ and $\mathrm{N}_{1}$ (21.78 and 22.24 seeds pod $^{-1}$ respectively).

Finally, as shown in Table 3, year, variety and nitrogen application affected significantly the 1000-seed weight, whereas the influence of the interaction of nitrogen by variety was not significant. Nitrogen rate of $90 \mathrm{~kg} \mathrm{Nha}^{-1}$ improved 1000 -seed weight by about $0.6 \mathrm{~g}$, raising from $3.21 \mathrm{~g}$, in absence of nitrogen fertilization, to $3.81 \mathrm{~g}$ with application of $90 \mathrm{~kg} \mathrm{Nha}^{-1}$. Regarding the studied varieties, "Narjisse" exhibited the highest 1000-seed weight (3.71 g), while "Alia" showed the lowest one (3.42 g).

\subsection{Relationships among seed yield per plant, dry matter, oil content, harvest index, and yield components}

The matrix of correlation among the studied parameters is shown in Table 4. The results of correlation evidenced that seed yield per plant was positively and significantly associated with dry matter $(r=0.949)$, harvest index $(r=0.640)$, plant height $(r=0.709)$ and seed yield components, specifically number of branches per plant, number of pods per plant, and number of seeds per pod. Nevertheless no relationships were found between seed yield and seed oil content and 1000-seed weight. Seed oil content was positively associated with dry matter, branches number per plant, pod number per plant and 1000-seed weight. However, no significant correlations were revealed between this trait and seed yield, harvest index, plant height and seeds per pod (Tab. 4).

\section{Discussion}

Overall, the effect of growing season (year) was highly significant on all studied parameters. The significant effect of year on yield may be due to the differences of weather conditions of each growth season, particularly the rainfall and its distribution throughout the growing season. It was reported that weather conditions (rainfall, temperature) were major factors affecting yield in rapeseed and seasonal water distribution throughout the season was more critical for successful canola production than total water supply (Assefa et al., 2018). The present study indicated also that seed yield was considerably improved by increasing the nitrogen level of the soil. This amelioration in seed yield is a result of an increase in the main yield components, especially number of pods per plant and number of seeds per pod. Various authors have reported that high rapeseed yields demand high $\mathrm{N}$ rates application to soil; $150 \mathrm{~kg} \mathrm{Nha}^{-1}$ in United kingdom (Holmes, 1980), $180 \mathrm{~kg} \mathrm{Nha}^{-1}$ in China (Li et al., 2019), and $213 \mathrm{~kg} \mathrm{Nha}^{-1}$ in Egypt (Ibrahim et al., 1989). Furthermore, Ahmadi and Bahrani (2009) in Iran reported that the highest yield in rapeseed was obtained with a fertilization rate of $225 \mathrm{~kg} \mathrm{~N} \mathrm{ha}^{-1}$. This linear relationship between seed yield and $\mathrm{N}$ rate could be attributed to the higher number of pods per plant, and seeds per pod (Ghanbari-Malidarreh, 2010; Imran et al., 2014), which supports our findings. Indeed, the relation between yield and the two yield components was yield= $-6.449+0.048 \times$ number of pods palnt ${ }^{-1}+0.371 \times$ number of seed by pod with $R^{2}=0.871$. 
Table 4. Correlation coefficients among the different studied traits of rapeseed.

\begin{tabular}{|c|c|c|c|c|c|c|c|c|c|}
\hline Traits & $\begin{array}{l}\text { Seed } \\
\text { yield }\end{array}$ & $\begin{array}{l}\text { Oil } \\
\text { content }\end{array}$ & $\begin{array}{l}\text { Dry } \\
\text { matter }\end{array}$ & $\begin{array}{l}\text { Harvest } \\
\text { index }\end{array}$ & $\begin{array}{l}\text { Plant } \\
\text { height }\end{array}$ & $\begin{array}{l}\text { Branches } \\
\text { number }\end{array}$ & $\begin{array}{l}\text { Pod } \\
\text { number }\end{array}$ & $\begin{array}{l}\text { Seeds } \\
\text { per pod }\end{array}$ & $\begin{array}{l}1000 \text {-seeds } \\
\text { weight }\end{array}$ \\
\hline Seed yield & - & - & - & - & - & - & - & - & - \\
\hline Dry matter & $0.949 * * *$ & $0.185^{*}$ & - & - & - & - & - & - & - \\
\hline Harvest index & $0.640 * * *$ & $-0.078 \mathrm{~ns}$ & $0.407 * * *$ & - & - & - & - & - & - \\
\hline Plant height & $0.709 * * *$ & $-0.021 \mathrm{~ns}$ & $0.706^{* * *}$ & $0.480 * * *$ & - & - & - & - & - \\
\hline Pod number & $0.934 * * *$ & $0.216^{*}$ & $0.976^{* * *}$ & $0.421 * * *$ & $0.723 * * *$ & $0.852 * * *$ & - & - & - \\
\hline Seeds per pod & $0.773 * * *$ & $0.101 \mathrm{~ns}$ & $0.765^{* * *}$ & $0.485 * * *$ & $0.671 * * *$ & $0.673 * * *$ & $0.730 * * *$ & - & - \\
\hline 1000 -seed weight & $-0.005 \mathrm{~ns}$ & $-0.418^{* * *}$ & $-0.019 \mathrm{~ns}$ & $-0.040 \mathrm{~ns}$ & $0.038 \mathrm{~ns}$ & $-0.051 \mathrm{~ns}$ & $-0.036 \mathrm{~ns}$ & $-0.00047 \mathrm{~ns}$ & - \\
\hline
\end{tabular}

ns: not significant; $* * *$, and $* * *$ : significant at $0.05,0.01$, and 0.001 probability level, respectively.

Our study showed a significant variation among rapeseed varieties in seed yield. the results obtained are in line with $\mathrm{He}$ and Yang (2017) who reported that seed yield per plant was significantly affected mainly by genotype and nitrogen rate, but not by their interaction. Many other authors found a significant effect of genotype on seed yield in rapeseed response to the nitrogen supply (Li et al., 2019; Özer, 2003; Marjanović-Jeromela et al., 2019; Svečnjak and Rengel, 2006; Zhang et al., 2012). Regardless of the nitrogen rate applied, seed yield ranged from 8.20 to $9.82 \mathrm{~g} \mathrm{plant}^{-1}$, and these values are substantially higher than those reported by Svečnjak and Rengel (2006), which varied from 3.7 to $5.1 \mathrm{~g} \mathrm{plant}^{-1}$, even they used nitrogen dose much higher than ours. The differences recorded could be explained by the cultivars potential and the environmental conditions where those cultivars were grown.

The effect of $\mathrm{N}$ application level and variety on dry matter production in rapeseed has been largely studied. Generally, increasing nitrogen rate leads to an increase in dry matter accumulation of rapeseed. Similarly to seed yield, dry matter was significantly influenced by nitrogen rate and variety. This is in agreement with other previous studies (Balint et al., 2008; He and Yang, 2017; Yau and Thurling, 1987). However, in other contexts, dry matter production could be increased only by raising the nitrogen rate without any significant effect of the rapeseed cultivar (Asare and Scarisbrick, 1995).

Regarding harvest index (HI), our results evidenced the significant effect of the variety, the nitrogen doses, and their interaction. Similar findings were reported by Yau and Thurling (1987). However, in other studies, HI was found to be considerably affected only by $\mathrm{N}$ fertilization, with no significant effect of variety or variety $\times$ nitrogen interaction (Baghdadi et al., 2014; Schulte auf'm Erley et al., 2011). By contrast, Svečnjak and Rengel (2006) reported that nitrogen rate did not impact significantly harvest index, which was mainly and significantly influenced by the rapeseed cultivars. In the present investigation, HI varied from $24.90 \%$ in the variety "Lila" to $27.42 \%$ in the variety "Alia" and from $22.95 \%$, without $\mathrm{N}$ fertilization $\left(\mathrm{N}_{0}\right)$, to $28.43 \%$ under $90 \mathrm{~N} \mathrm{~kg} \mathrm{ha}^{-1}$. These values are much lower than those of Rafiqul et al. (2018) who found that HI rose from $36.22 \%$, in absence of $\mathrm{N}$ fertilization, to $40.54 \%$ for application of $180 \mathrm{~kg} \mathrm{ha}^{-1}$. Besides of the impact of the nitrogen doses applied, HI was much dependent on environmental factors (Baghdadi et al., 2014).

For plant height, there was a significant effect of the variety and the nitrogen application, which was in agreement with Özer (2003) and Ma et al. (2015). Increasing plant height through genetic approach (variety) or nitrogen application may be a good strategy to improve seed yield as there was a strong and positive correlation among both traits $(0.71)$. Furthermore, plant height has also positively and strongly associated with branching and seed yield components as shown in Table 4. Nevertheless, higher cultivars should be resistant to lodging and grown under favorable environmental conditions, particularly characterized by the absence of drought or heat stresses.

As expected, our study showed positive effect of high nitrogen level on yield components, as well as branches number per plant, pods number per plant, seeds per pod, and seed weight. Also, previous works on rapeseed showed that high levels of applied nitrogen led to the improvement of yield components (Ahmad et al., 2011; Bybordi, 2014; Kamkar et al., 2011; Khan et al., 2017; Ozer, 2003). The increase in some yield components, as a result of application of high nitrogen rate, may be due to the increase of leaf growth, which is considered as an important factor affecting pod and seed growth and development in rapeseed (Kamkar et al., 2011). In concordance with our findings, Sana et al. (2002) and Kamkar et al. (2011) also showed a genotypic variation in yield components that may be attributed to the genetic background and the environmental conditions. Kamkar et al. (2011) reported that by elevating nitrogen rate from 0 to $270 \mathrm{~kg} \mathrm{~N}$ $\mathrm{ha}^{-1}$, number of pod per plant grow up from 73 to 190 , while number of seeds per pod increased from 20 to 25 , which was in agreement with our findings even we used much lower nitrogen rates.

With regard to oil content, our results were in agreement with those of many previous studies having reported the significant impact of variety and nitrogen application on this parameter (Ahmad et al., 2011; Balint and Rengel, 2008; Bouchet et al., 2014; Poisson et al., 2019; Sana et al., 2002). The observed drop in seed oil content occurring with the increase of nitrogen doses, may be due to the dilution effect of increased seed yield with increased $\mathrm{N}$ fertilization and the inverse relationship of protein and oil content (Kutcher et al., 2005). However, it was noticed that an improvement of oil 
yield as a result of increasing nitrogen rate, which can be due to the substantial amelioration of seed yield (Cheema et al., 2001; Imran et al., 2014). No significant effect of the interaction variety by nitrogen was observed by this study, which may be explained by the same ranking of the five varieties in their response to nitrogen levels.

The analysis of correlation among the traits studied revealed strong and positive associations between plant height, branch number, pods per plant, and seeds per pod. This may be explained by the fact that increment in plant height achieved to the increase in branch number and, consequently, to the increase in yield components. Our results were in good accordance with Marjanović-Jeromela et al. (2008). Furthermore, seed yield per plant was significantly and positively correlated with all yield components except 1000-seed weight. Similar results were reported by Cong et al. (2019) who stated that seed weight was an inherent trait that was mainly governed by the genotype and has showed less variability with fertilizer application. In addition, Diepenbrock (2000) reported that 1000-seed weight, being the last yield component to be accomplished during development, depended to a lesser extent on environmental conditions than other components. In our study, we observed a strong and positive relationship between seed yield and its components, number of pods per plant and number of seeds per pod. This was in perfect agreement with findings of Lu et al. (2011) who reported that pods per plant and seeds per pod were the most important yield components as they were the direct factors for seed yield formation. Finally, seed yield per plant was found to be strongly and positively associated with dry matter per plant $(r=0.95)$ and harvest index $(r=0.64)$. Similar results were reported by Zuo et al. (2019) and Ali et al. (2003) who also recorded positive relationship between seed yield per plant and harvest index, with a correlation coefficient of 0.57 , slightly lower than ours. The association between oil content and seed yield per plant was positive but not significant with a low correlation coefficient of about 0.13 . Other previous authors have registered a weak and non-significant or even no correlation between both traits (Tunçtürk and Çidot, 2007; Özer et al., 1999).

\section{Conclusion}

The response of five Moroccan rapeseed varieties to different nitrogen rates was investigated for the first time. By increasing the level of the fertilization applied, there was a substantial improvement in seed, mainly due to a significant raise in dry matter, number of pods per plant and number of seeds per pod. Actually, the nitrogen rate of $90 \mathrm{~kg} \mathrm{~N} \mathrm{ha}^{-1}$ was the best regardless of the varieties studied. Also, these varieties showed a positive response to the increase of nitrogen rate. However, no significant interaction between both factors. For all nitrogen rates combined, the varieties "Alia" and "Moufida" were found to be the best in terms of seed and oil yield. Additional studies, through different environments, on the same varieties and including higher nitrogen rates (120 and $150 \mathrm{~kg} \mathrm{Nha}^{-1}$ ) are needed to look for the optimal nitrogen application and identify the most efficient variety.

Acknowledgments. We are grateful to M. Sarsri Abdeslam, head of the Educational and Research farm at the National
School of Agriculture (ENAM), and his team, for their technical assistance and valuable collaboration.

\section{References}

Ahmad G, Jan A, Arif M, Jan MT, Shah H. 2011. Effect of nitrogen and sulfur fertilization on yield components, seed and oil yields of canola. J Plant Nutr 34(14): 2069-2082. https://doi.org/10.1080/ 01904167.2011 .618569$.

Ahmadi M, Bahrani MJ. 2009. Yield and yield components of rapeseed as influenced by water stress at different growth stages and nitrogen levels. Am Eurasian J Agric Environ Sci 5(6): 755-761.

Al-Solaimani SG, Alghabari F, Ihsan MZ. 2015. Effect of different rates of nitrogen fertilizer on growth, seed yield, yield components and quality of canola (Brassica napus L.) under arid environment of Saudi Arabia. Int J Agron Agri Res 6(4): 268-274.

Ali N, Javidfar F, Elmira JY, Mirza MY. 2003. Relationship among yield components and selection criteria for yield improvement in winter rapeseed (Brassica napus L.). Pak J Bot 35(2): $167-174$

Anonymous. 2021. Filière oléagineuse. Available from https://www. agriculture.gov.ma/fr/filiere/oleagineuses\#indicateurs-1 (last consult: 2021/12/08).

Asare E, Scarisbrick DH. 1995. Rate of nitrogen and sulphur fertilizers on yield, yield components and seed quality of oilseed rape (Brassica napus L.). Field Crops Res 44(1): 41-46. https:// doi.org/10.1016/0378-4290(95)00051-7.

Assefa Y, Vara Prasad PV, Foster C, et al. 2018. Major management factors determining spring and winter canola yield in North America. Crop Sci 58(1): 1-16. https://doi.org/10.2135/ cropsci2017.02.0079.

Baghdadi A, Halim RA, Shahriari A. 2014. Canola production under nitrogen fertilizer at different stages of plant growth in a crop rotation system Canola production under nitrogen fertilizer at different stages of plant growth in a crop rotation system. $J$ Food Agric Environ 12(2): 292-295.

Balint T, Rengel Z. 2008. Nitrogen efficiency of canola genotypes varies between vegetative stage and grain maturity. Euphytica 164 (2): 421-432. https://doi.org/10.1007/s10681-008-9693-6.

Balint T, Rengel Z, Allen D. 2008. Australian canola germplasm differs in nitrogen and sulfur efficiency. Aust J Agric Res 59(2): 167-174. https://doi.org/10.1071/AR06255.

Bouchet AS, Nesi N, Bissuel C, et al. 2014. Genetic control of yield and yield components in winter oilseed rape (Brassica napus L.) grown under nitrogen limitation. Euphytica 199(1-2): 183-205. https://doi.org/10.1007/s10681-014-1130-4.

Brennan RF, Bolland MDA. 2007. Effect of fertiliser phosphorus and nitrogen on the concentrations of oil and protein in grain and the grain yield of canola (Brassica napus L.) grown in south-western Australia. Aust J Exp Agric 47: 984-991. https://doi.org/10.1071/ EA06115.

Bybordi A. 2014. Efficacy of integrated fertilizer management to improve agronomic and physiological traits of canola cultivars. Arch Agron Soil Sci 60(7): 935-950. https://doi.org/10.1080/ 03650340.2013 .857404$.

Cheema MA, Malik MA, Hussain A, et al. 2001. Effects of time and rate of nitrogen and phosphorus application on the growth and the seed and oil yields of canola (Brassica napus L.). J Agron Crop Sci 186(2): 103-110. https://doi.org/10.1046/ j.1439-037X.2001.00463.x. 
Cong R, Wang Y, Li X, Ren T, Lu J. 2019. Differential responses of seed yield and yield components to nutrient deficiency between direct sown and transplanted winter oilseed rape. Int J Plant Prod 14(1): 77-92. https://doi.org/10.1007/s42106-019-00069-1.

Diepenbrock W. 2000. Yield analysis of winter oilseed rape (Brassica napus L.): a review. Field Crops Res 67(1): 35-49. https://doi.org/ 10.1016/S0378-4290(00)00082-4.

FAOSTAT. 2021. Available from http://www.fao.org/faostat/fr/\#data/ QCL (last consult: 2021/12/08).

Galloway JN, Leach AM, Bleeker A, Erisman JW. 2013. A chronology of human understanding of the nitrogen cycle. Philos Trans R Soc B Biol Sci 368(1621): 20130120-20130120. https:// doi.org/10.1098/rstb.2013.0120.

Ghanbari-Malidarreh A. 2010. Effects of nitrogen rates and splitting on oil content and seed yield of canola (Brassica napus L.). Am Eurasian J Agric Environ Sci 8(2): 161-166.

He H, Yang R, Li Y, et al. 2017. Genotypic variation in nitrogen utilization efficiency of oilseed rape (Brassica napus L.) under contrasting N supply in pot and field experiments. Front Plant Sci 8: 1825. https://doi.org/10.3389/fpls.2017.01825.

Hocking PJ, Randall PJ, DeMarco D. 1997. The response of dryland canola to nitrogen fertilizer: partitioning and mobilization of dry matter and nitrogen, and nitrogen effects on yield components. Field Crops Res 54(2-3): 201-220. https://doi.org/10.1016/ S0378-4290(97)00049-X.

Hocking PJ, Stapper M. 2001. Effects of sowing time and nitrogen fertiliser on canola and wheat, and nitrogen fertiliser on Indian mustard. II. Nitrogen concentrations, $\mathrm{N}$ accumulation, and $\mathrm{N}$ fertiliser use efficiency. Aust J Agric Res 52(6): 635-644. https:// doi.org/10.1071/ar00114.

Holmes MRJ. 1980. Nutrition of the oilseed rape crop. London: Applied Scientific Publishers.

Ibrahim AF, Abusteit EO, El-Metwally EA. 1989. Response of rapeseed (Brassica napus L.) growth, yield, oil content and its fatty acids to nitrogen rates and application times. J Agron Crop Sci 162(2): 107-112. https://doi.org/10.1111/j.1439-037X.1989. tb00695.x.

Imran K, Irfanullah AA, Ahmad F. 2014. Production potential of rapeseed (Brassica napus L.) as influenced by different nitrogen levels and decapitation stress under the rainfed agro-climatic condition of Swat-Pakistan. J Glob Innov Agric Soc Sci 2: 112115. https://doi.org/10.17957/JGIASS/2.3.573.

Jackson GD. 2000. Effects of nitrogen and sulfur on canola yield and nutrient uptake. Agron J 92: 644-649.

Jackson GD, Kushnak GD, Welty LE, et al. 1993. Fertilizing canola. Montana Ag Research 10(2): 21-24.

Kamkar B, Daneshmand AR, Ghooshchi F, et al. 2011. The effects of irrigation regimes and nitrogen rates on some agronomic traits of canola under a semiarid environment. Agric Water Manage 98(6): 1005-1012. https://doi.org/10.1016/j.agwat.2011.01.009.

Khan S, Anwar S, Kuai J, et al. 2017. Optimization of nitrogen rate and planting density for improving yield, nitrogen use efficiency, and lodging resistance in oilseed rape. Front Plant Sci 8: 532. https://doi.org/10.3389/fpls.2017.00532.

Kutcher HR, Malhi SS, Gill KS. 2005. Topography and management of nitrogen and fungicide affects diseases and productivity of canola. Agron J 97: 533-541. https://doi.org/10.2134/ agronj2005.0533.

Li H, Ghafoor A, Karim H, et al. 2019. Optimal nitrogen fertilization management of seed-sowing rapeseed in Yangtze River Basin of China. Pak J Biol Sci 11: 291-298. https://doi.org/10.3923/ pjbs.2019.291.298.
Lin Y, Watts DB, Torbert HA, Howe JA. 2020. Influence of nitrogen rate on winter canola production in the southeastern United States. Agron J 112: 2978-2987. https://doi.org/10.1002/agj2.20197.

Lu GY, Zhang F, Zheng PY, et al. 2011. Relationship among yield components and selection criteria for yield improvement in early rapeseed (Brassica napus L.). Agric Sci China 10(7): 997-1003. https://doi.org/10.1016/S1671-2927(11)60086-2.

Ma BL, Biswas DK, Herath AW, et al. 2015. Growth, yield, and yield components of canola as affected by nitrogen, sulfur, and boron application. J Plant Nutr Soil Sci 178(4): 658-670. https://doi.org/ 10.1002/jpln.201400280.

Ma BL, Herath AW. 2016. Timing and rates of nitrogen fertiliser application on seed yield, quality and nitrogen-use efficiency of canola. Crop Pasture Sci 167-180. https://doi.org/10.1071/CP15069.

Marjanović-Jeromela A, Marinkovi R, Zdunic Z, Ivanovska S, Jankulovska M. 2008. Correlation and path analysis of quantitative traits in winter rapeseed (Brassica napus L.). Agriculturae Conspectus Scientificus 73: 13-18.

Marjanović-Jeromela A, Terzić S, Jankulovska M, et al. 2019. Dissection of year related climatic variables and their effect on winter rapeseed (Brassica napus L.) development and yield. Agron 9: 517. https://doi.org/10.3390/agronomy9090517.

Nabloussi A. 2015. Amélioration génétique du colza : enjeux et réalisations pour un développement durable de la filière. Éditions INRA/DIC. ISBN: 978-9954-593-27-1.

Naderifar M, Daneshian J. 2012. Effect of different nitrogen and biofertilizers effect on growth and yield of Brassica napus L. Int J Agric Crop Sci 4: 478-482.

Özer H. 2003. Sowing date and nitrogen rate effects on growth, yield and yield components of two summer rapeseed cultivars. Eur J Agron 19 (3): 453-463. https://doi.org/10.1016/S1161-0301(02)00136-3.

Özer H, Oral E, Dogru U. 1999. Relationship between yield and yield components on currently improved spring rapeseed cultivars. Turk J Agric For 23: 603-607.

Öztürk Ö. 2010. Effects of source and rate of nitrogen fertilizer on yield, yield components and quality of winter rapeseed (Brassica napus L.). Chilean Journal of Agricultural Research 70(1): 132141. https://doi.org/10.4067/S0718-58392010000100014.

Poisson E, Trouverie J, Brunel-Muguet S, et al. 2019. Seed yield components and seed quality of oilseed rape are impacted by sulfur fertilization and its interactions with nitrogen fertilization. Front Plant Sci 10: 1-14. https://doi.org/10.3389/fpls.2019.00458.

Rafiqul I, Hakim HTHMF, Haque MN. 2018. Yield and yield components of rapeseed as influenced by nitrogen and sulphur fertilization. J Oilseed Brassica 9: 84-95.

Raman H, Uppal RK, Raman R. 2019. Genetic solutions to improve resilience of canola to climate change. In: Kole C, ed. Genomic designing of climate-smart oilseed crops. Berlin (Germany): Springer International Publishing, pp. 75-131.

Rathke GW, Behrens T, Diepenbrock, W. 2006. Integrated nitrogen management strategies to improve seed yield, oil content and nitrogen efficiency of winter oilseed rape (Brassica napus L.): a review. Agric Ecosyst Environ 117(2-3): 80-108. https://doi.org/ 10.1016/j.agee.2006.04.006.

Riar A, Gill G, McDonald GK. 2020. Rate of nitrogen rather than timing of application influence yield and NUE of canola in south Australian Mediterranean environments. Agron 10(10): 1505. https://doi.org/10.3390/agronomy10101505.

Sana M, Asghar A, Asghar M, et al. 2002. Comparative yield potential and oil contents of different canola cultivars (Brassica napus L.). Pak J Agron 2(1): 1-7. https://doi.org/10.3923/ ja.2003.1.7. 
Schjoerring JK, Bock JGH, Gammelvind L, et al. 1995. Nitrogen incorporation and remobilization in different shoot components of field-grown winter oilseed rape (Brassica napus L.) as affected by rate of nitrogen application and irrigation. Plant Soil 177: 255264. https://doi.org/10.1007/BF00010132.

Schulte auf'm Erley G, Behrens T, Ulas A, et al. 2011. Agronomic traits contributing to nitrogen efficiency of winter oilseed rape cultivars. Field Crops Res 124(1): 114-123. https://doi.org/ 10.1016/j.fcr.2011.06.009.

Stahl A, Vollrath P, Samans B, et al. 2019. Effect of breeding on nitrogen use efficiency-associated traits, in oilseed rape. $J$ Exp Bot 70(6): 1969-1986. https://doi.org/10.1093/jxb/erz044.

Svečnjak Z, Rengel Z. 2006. Nitrogen utilization efficiency in canola cultivars at grain harvest. Plant and Soil 283(1-2): 299-307. https://doi.org/10.1007/s11104-006-0020-5.

Tunçtürk M, Çidot V. 2007. Relationships between yield and some yield components in rapeseed (Brassica napus ssp. oleifera L.) cultivars by using correlation and path analysis. Pak J Bot 39(1): 81-84.

Yau SK, Thurling N. 1987. Variation in nitrogen response among spring rape (Brassica napus L.) cultivars and its relationship to nitrogen uptake and utilization. Field Crops Res 16(2): 139-155. https://doi.org/10.1016/0378-4290(87)90004-9

Zhang CL, Li J, Yu LP, Li F, Ma N. 2010. Input/output analysis on rapeseed production practices under different cultivation mode. Chinese J Oil Crop Sci 32(1): 57-64 (in Chinese).

Zhang Z, Song H, Liu Q, et al. 2012. Responses of seed yield and quality to nitrogen application levels in two oilseed rape (Brassica napus L.) varieties differing in nitrogen efficiency. Plant Prod Sci 15(4): 265-269. https://doi.org/10.1626/pps.15.265.

Zuo Q, Liu J, Wang L, et al. 2019. Yield, dry matter and N characteristics in canola as affected by fertilizer $\mathrm{N}$ rate and split-application ratio under high soil fertility condition. J Plant Nutr 43(5): 655-666. https://doi.org/10.1080/01904167.2019.1701026.

Cite this article as: Yahbi M, Nabloussi A, Maataoui A, El Alami N, Boutagayout A, Daoui K. 2022. Effects of nitrogen rates on yield, yield components, and other related attributes of different rapeseed (Brassica napus L.) varieties. OCL 29: 8. 